\title{
PERSEPSI UMKM DALAM MEMAHAMI SAK EMKM
}

\section{SMES PERCEPTIONS IN UNDERSTANDING THE ACCOUNTING STANDARD FOR SMES}

\author{
I.C. Kusuma, V. Lutfiany \\ Jurusan Akuntansi Fakultas Ekonomi Universitas Djuanda Bogor \\ E-mail : vialutfiany@gmail.com
}

\begin{abstract}
This research aims to determine the influence of SAK EMKM socialization, owner's educational level, perception actors of MSMEs, and accounting comprehension on the implementation of SAK EMKM at MSMEs in Bogor city. And to determine the most dominant influence on the implementation of SAK EMKM. The design is using survey method with causal associative technique. To get sample use purposive sampling technique, so that selected 96 owner's of MSMEs in Bogor city. Analyze of data using multiple linear regression. The result showed that the SAK EMKM socialization, owner's educational level, perception actors of MSMEs, and accounting comprehension take positive and significant effect on the implementation of SAK EMKM. Partially shows that all the variables take positive and significant effect on the implementation of SAK EMKM the MSMEs in Bogor city. Contribution amount influence of socialization, owner's educational level, perception actors of MSMEs, and accounting comprehension on the implementation of SAK EMKM is 57,5\%. Accounting Comprehension is the most dominant variable on the implementation of SAK EMKM.
\end{abstract}

Keywords : SAK EMKM, Socialization, Owner's Educational Level, Perception, Accounting Comprehension

\begin{abstract}
ABSTRAK
Penelitian ini bertujuan untuk mengetahui pengaruh sosialisasi SAK EMKM, tingkat pendidikan pemilik, persepsi pelaku UMKM dan pemahaman akuntansi terhadap implementasi SAK EMKM pada UMKM di Kota Bogor. Dan untuk mengetahui faktor yang paling dominan dalam implementasi SAK EMKM. Desain penelitian ini menggunakan metode survey dengan teknik asosiatif kausal. Penentuan sampel menggunakan purposive sampling sehingga terpilih 96 pemilik UMKM di Kota Bogor. Teknik analisis data menggunakan analisis regresi linier berganda. Hasil penelitian menunjukan bahwa sosialisasi SAK EMKM, tingkat pendidikan pemilik, persepsi pelaku UMKM dan pemahaman akuntansi secara simultan berpengaruh positif dan signifikan terhadap implementasi SAK EMKM. Secara parsial menunjukan bahwa semua indikator berpengaruh positif dan signifikan terhadap implementasi SAK EMKM pada UMKM di Kota Bogor. Besarnya kontribusi pengaruh sosialisasi SAK EMKM, tingkat pendidikan pemilik, persepsi pelaku UMKM dan pemahaman akuntansi terhadap implementasi SAK EMKM yaitu sebesar 57,5\%. Pemahaman akuntansi merupakan variabel yang paling dominan terhadap implementasi SAK EMKM.
\end{abstract}

Kata Kunci : SAK EMKM, Sosialisasi, Tingkat Pendidikan Pemilik, Persepsi, Pemahaman Akuntansi 


\section{PENDAHULUAN}

Indonesia merupakan negara berkembang yang menitikberatkan pertumbuhan ekonomi dan pembangunan ke arah yang lebih baik. Ini sudah dimulai dengan adanya bentuk usaha-usaha berskala besar maupun kecil yang amat beragam. Salah satu jenis usaha yang terdapat di Indonesia yaitu Usaha Mikro, Kecil dan Menengah (UMKM). Bidang usaha yang salah satunya dapat berkembang dalam perekonomian nasional yaitu UMKM. UMKM merupakan sebuah tempat yang baik bagi penciptaan lapangan pekerjaan dan pertumbuhan ekonomi.

Peran UMKM dalam perekonomian Indonesia yaitu menghasilkan output yang berguna bagi masyarakat. Namun UMKM dihadapkan pada salah satu kendala yang biasanya terjadi dalam usaha yaitu keterbatasan dalam pembuatan laporan keuangan. Setiap aktivitas yang dilakukan oleh UMKM memerlukan sebuah laporan keuangan yang mencerminkan kegiatan usahanya selama satu periode akuntansi.

Demi terpenuhinya kebutuhan informasi bagi UMKM maka Dewan Standar Akuntansi Keuangan Ikatan Akuntan Indonesia (DSAK IAI) ketika tahun 2009 menyusun dan mensahkan Standar yang diadopsi dari International Financial Reporting Standard for Small Medium Enterprises (IFRS for SMEs) yang lebih sederhana yaitu Standar Akuntansi Keuangan Entitas Tanpa Akuntabilitas Publik (SAKETAP). Namun mulai saat disahkan hingga sekarang masih menunjukkan belum maksimal pengimplementasian SAK ETAP yang oleh para pelaku usaha. Hal tersebut disebabkan oleh rendahnya pengetahuan dan kurangnya informasi yang menghasilkan rendahnya motivasi untuk menerapkan pelaporan sesuai standar akuntansi. Terkait dengan hal tersebut untuk membantu EMKM untuk dapat menyajikan laporan keuangan, DSAK IAI pada tanggal 24 Oktober 2016 menyusun dan mensahkan exposure draft Standar Akuntansi Keuangan Entitas Mikro, Kecil, dan Menengah (SAK EMKM) yang berisikan konsep yang tidak terlalu rumit atau dapat dikatakan sederhana dibandingkan dengan SAK ETAP.

Penyusunan dan pembuatan SAK EMKM didasarkan pada UU No.20 tahun 2008 tentang UMKM. Standar ini diterbitkan dengan harapan dapat membantu UMKM untuk dapat menerapkan akuntansi sesuai standar yang selama ini masih dianggap rumit jika menggunakan SAK ETAP. Penggunaan SAK EMKM ini ditujukan untuk pengguna eksternal entitas mikro, kecil dan menengah seperti pemilik yang tidak terjun langsung dalam pengelolaan usaha dan kreditur, dimana penggunaan laporan keuangan pada UMKM cenderung tidak membutuhkan laporan keuangan rumit dan analisis laporan keuangan secara mendalam.

Kebijakan SAK baru telah disahkan, sehingga perlu ada sosialisasi, karena dengan cara sosialisasi maka akan menimbulkan pemahaman yang baik tentang SAK. Sosialisasi berperan aktif dalam suatu kedudukan ataupun peranan tertentu di masyarakat yang merupakan hasil dari proses seseorang memperoleh pengetahuan, keterampilan dan sikap yang dilakukannya (Richer dalam Dewi, Yuniarta dan Wahyuni, 2017:4). Implementasi tentang SAK EMKM juga dipengaruhi oleh tingkat pendidikan pemilik UMKM itu sendiri. Kemampuan dan keahlian baik pemilik maupun manajer perusahaan menengah ataupun kecil saat ini sangat ditentukan dari pendidikan yang pernah ditempuh baik formal maupun non formal (Muniarti, 2002:138). Persepsi pelaku UMKM juga mempengaruhi implementasi SAK EMKM, setiap pemilik memiliki persepsi yang berbeda-beda mengenai penggunaan SAK yang berlaku. Persepsi merupakan bagaimana orang-orang melihat atau menginterpretasikan baik peristiwa, objek maupun manusia (Dewi, Yuniarta dan Wahyuni, 2017:4). Pemahaman dalam akuntansi juga dibutuhkan agar menjadi dasar dalam memahami dan mengimplementasikan laporan keuangan sesuai SAK EMKM. Kemampuan dalam menangkap baik arti maupun makna dari bahan yang dipelajari merupakan suatu pemahaman (Winkel, 2004:274). Semakin baik pemahaman akuntansi yang dimiliki pemilik ataupun 
manajer, semakin bagus kemampuan mereka dalam mengimplementasikan SAK EMKM ke dalam laporan keuangan.

Berdasarkan hal tersebut maka penulis tertarik untuk melakukan penelitian yang berjudul "Pengaruh Sosialisasi SAK EMKM, Tingkat Pendidikan Pemilik, Persepsi Pelaku UMKM dan Pemahaman Akuntansi terhadap Implementasi SAK EMKM pada UMKM di Kota Bogor".

Tujuan dalam penelitian ini adalah sebagai berikut :

1. Untuk mengetahui Pengaruh Sosialisasi SAK EMKM, Tingkat Pendidikan Pemilik, Persepsi Pelaku UMKM dan Pemahaman Akuntansi secara simultan terhadap Implementasi SAK EMKM di Kota Bogor.

2. Untuk mengetahui Pengaruh Sosialisasi SAK EMKM, Tingkat Pendidikan Pemilik, Persepsi Pelaku UMKM dan Pemahaman Akuntansi secara parsial terhadap Implementasi SAK EMKM di Kota Bogor.

3. Untuk mengetahui faktor yang paling dominan dari Sosialisasi SAK EMKM, Tingkat Pendidikan Pemilik, Persepsi Pelaku UMKM dan Pemahaman Akuntansi terhadap Implementasi SAK EMKM pada UMKM di Kota Bogor.

Dengan dilakukannya penelitian ini diharapkan dapat bermanfaat baik bagi peneliti, bagi pelaku UMKM dan juga bagi lingkungan akademik. Karena dari penelitian ini dapat memperluas wawasan penulis dan menambah ilmu pengetahuan mengenai sosialisasi SAK EMKM, tingkat pendidikan pemilik, persepsi pelaku UMKM dan pemahaman akuntansi serta pengaruhnya terhadap implementasi SAK EMKM pada UMKM di Kota Bogor, dapat memberikan informasi yang berguna bagi pemilik umkm di Kota Bogor akan pentingnya menerapkan laporan keuangan sesuai SAK yang berlaku, sebagai masukan ataupun evaluasi untuk meningkatkan kinerja penyusunan laporan keuangan, juga diharapkan memberikan manfaat sebagai bahan referensi bagi penelitian selanjutnya yang ingin melakukan penelitian tentang umkm dan berbagai literatur penambah ilmu pengetahuan di bidang akuntansi keuangan.

\section{Tinjauan Teori Dan Pengembangan Hipotesis}

\section{Sosialisasi SAK EMKM}

Sosialisasi terjadi melalui kondisi lingkungan yang menyebabkan individu mempelajari pola kebudayaan fundamental. Makna penyesuaian diri (adjusment) identik dengan sosialisasi. Sosialisasi dapat dipandang sebagai suatu rangkaian belajar mengajar. Sosialisasi yang dilakukan berfungsi sebagai peran dalam suatu kedudukan atau peranan tertentu yang merupakan hasil dari rangkaian seseorang memperoleh pengetahuan, keterampilan dan sikap. (Richer dalam Dewi, Yuniarta dan Wahyuni, 2017:4).

\section{Tingkat Pendidikan Pemilik}

Proses mengubah sikap seorang atau sekelompok orang dalam usaha mendewasakan pola berfikir melalui upaya sebuah pengajaran dan pelatihan yang sesuai prosedur merupakan suatu pendidikan. Perbaikan kinerja perusahaan dan peningkatan daya saing dapat dilihat dari tingkat pendidikan seseorang baik pemilik dan juga karyawan (Hariandja, 2002:169).

\section{Persepsi Pelaku UMKM}

Persepsi dapat diartikan sebagai penglihatan, bagaimana cara seseorang melihat sesuatu. Penjelasan dari arti tersebut yaitu sebuah pandangan atau pengertian seseorang dalam mengartikan sesuatu. Secara formal, persepsi merupakan suatu proses seseorang melakukan seleksi, mengorganisasikan, dan interpretasikan suatu hal ke dalam suatu gambaran yang lebih luas (dunia) yang memiliki arti dan menyeluruh (Simamora:2002).

\section{Pemahaman Akuntansi}

Pemahaman adalah kemampuan seseorang dalam mengerti dan memahami sesuatu. Memahami yaitu mengetahui suatu hal dan dapat dilihat dari berbagai segi. Ketika seseorang memberikan suatu penjelasan dan meneladani hal tersebut 
dengan menggunakan kalimat sendiri adalah yang dikatakan memahami hal tersebut (Mukmin dan Maemunah, 2018). Kemampuan dalam menangkap baik arti maupun makna dari bahan yang dipelajari merupakan suatu pemahaman (Winkel, 2004:274).

\section{Implementasi SAK EMKM}

Dalam pengimplementasiannya, SAK EMKM ditujukan untuk digunakan oleh pelaku UMKM yang belum mampu menyusun laporan keuangan sesuai SAK yang berlaku. Suatu aktivitas, aksi, tindakan maupun adanya mekanisme untuk suatu system merupakan sebuah implementasi (Usman, 2002:70). Implementasi dapat dikatakan kegiatan yang direncanakan dan dilakukan guna mencapai suatu tujuan kegiatan. Maka implementasi SAK EMKM dilakukan untuk agar EMKM membuat laporan keuangan lebih terarah.

Meidiyustiani (2016) dalam hasil penelitiannya menunjukan bahwa baik pendidikan pemilik maupun pemahaman akuntansi berpengaruh terhadap penerapan SAK ETAP. Dewi, Yuniarta dan Wahyuni (2017) untuk hasil penelitian menunjukkan bahwa membuktikan bahwa variabel sosialisasi SAK ETAP, tingkat pendidikan pemilik, dan juga persepsi pelaku UKM berpengaruh positif dan signifikan terhadap penggunaan SAK ETAP. Namun pada tahun 2016 DSAK IAI mengeluarkan dan mensahkan SAK baru yang dikhususkan untuk UMKM, yaitu SAK EMKM. Neag (2011) yang menyebutkan bahwa perlu dibuat peraturan untuk standarisasi dan format tetap untuk laporan keuangan di tingkat entitas mikro. Laporan keuangan dibuat demi kepentingan terbaik entitas yang dapat berguna untuk para pengguna informasi keuangan seperti kreditur, mitra komersial dan lembaga keuangan.

Setiap penelitian yang dilakukan terhadap suatu objek hendaknya menggunakan suatu tuntunan hipotesis yang berfungsi sebagai pegangan sementara atau jawaban sementara yang masih harus dibuktikan kebenarannya didalam kenyataan (emporocal verification), percobaan (experimentation) atau praktik (implementation), hal tersebut merupakan pola umum metode ilmiah (Supardi, 2005).

Hipotesis dalam penelitian ini adalah :

1. Diduga Sosialisasi SAK EMKM, Tingkat Pendidikan Pemilik, Persepsi Pelaku UMKM dan Pemahaman Akuntansi berpengaruh secara simultan positif dan signifikan terhadap Implementasi SAK EMKM pada UMKM di Kota Bogor.

2. Diduga Sosialisasi SAK EMKM, Tingkat Pendidikan Pemilik, Persepsi Pelaku UMKM dan Pemahaman Akuntansi berpengaruh secara parsial positif dan signifikan terhadap Implementasi SAK EMKM pada UMKM di Kota Bogor.

\section{METODE PENELITIAN}

Penelitian ini meneliti tentang pengaruh Sosialisasi SAK EMKM, Tingkat Pendidikan Pemilik, Persepsi Pelaku UMKM dan Pemahaman Akuntansi terhadap Implementasi SAK EMKM pada UMKM di Kota Bogor. Penelitian ini merupakan penelitian kuantitatif. Penelitian ini dikategorikan metode penelitian survei yang bersifat deskriptif, dengan teknik asosiatif kausal. Penggunaan teknik asosiatif kausal yaitu dengan menguji hipotesis hubungan variabel sebanyak dua atau lebih yang mengandung sebab akibat dan biasanya diawali dengan kata pengaruh atau faktor determinan.

\section{Variabel Penelitian dan Operasionalisasi Variabel}

Variabel Independent (variabel bebas) dalam penelitian ini adalah Sosialisasi SAK EMKM $\left(\mathrm{X}_{1}\right)$, Tingkat Pendidikan Pemilik $\left(\mathrm{X}_{2}\right)$, Persepsi Pelaku UMKM $\left(\mathrm{X}_{3}\right)$ dan Pemahaman Akuntansi $\left(\mathrm{X}_{4}\right)$. Variabel Dependent (variabel terikat) adalah implementasi SAK EMKM. Adapun indikator dari implementasi SAK EMKM, meliputi : melaksanakan penerapan SAK EMKM pada laporan keuangan UMKM dan mendapatkan pencapaian tujuan dari hasil laporan keuangan sesuai SAK. 


\section{Populasi, Sampel dan Teknik} Pengambilan Sampel

Dalam penelitian yang menjadi populasi adalah pemilik UMKM yang mendaftar langsung pada Dinas Koperasi dan UMKM Kota Bogor. Untuk pemilihan sampel menggunakan purposive sampling dengan kriteria sebagai berikut :

1. UMKM yang mendaftar langsung ke Dinas Koperasi dan UMKM Kota Bogor tahun 2016 - 2017 dan masih aktif dalam menjalankan usahanya.

2. UMKM yang telah membuat/menyusun laporan keuangan.

Dengan demikian, dalam penelitian ini diambil sampel data UMKM sesuai kriteria yaitu 96 responden.

\section{Pengujian Instrumen}

Berdasarkan data penelitian berupa kuesioner menurut Sugiyono (2013:136) dapat diolah dengan skala pengukuran likert. Pengolahan data ordinal menjadi analisis regresi terlebih dahulu harus ditransformasikan ke bentuk data interval dengan menggunakan rumus :

$\frac{\text { Nilai Tertinggi-Nilai Terendah }}{\text { Banyaknya kelas }}=\frac{5-1}{5}=0,8$

Berdasarkan hasil perhitungan panjang kelas interval tersebut diperoleh kriteria penilaian pada Tabel 1 :

\begin{tabular}{cc}
\multicolumn{2}{c}{ Tabel 1 Skala Penelitian } \\
\hline Skala & Interpretasi \\
\hline $1,00-1,80$ & Sangat Tidak Baik \\
$1,81-2,60$ & Tidak Baik \\
$2,61-3,40$ & Cukup \\
$3,41-4,20$ & Baik \\
$4,21-5,00$ & Sangat Baik \\
\hline Sumber : Sugiyono, 2014
\end{tabular}

\section{Pengujian Validitas}

Riduwan dan Sunarto (2007:348) Validitas adalah suatu ukuran yang menunjukan tingkat kevalidan atau kesahihan suatu instrumen penelitian. Sugiyono (2013:183) Item instrumen dianggap valid jika koefisien sama dengan atau lebih besar dari 0,3, jika kurang dari 0,3 maka item instrumen tersebut dinyatakan tidak valid.

\begin{tabular}{cc}
\multicolumn{2}{c}{ Tabel 2 Kriteria Uji Validitas } \\
\hline $\begin{array}{c}\text { Corrected Item Total } \\
\text { Corelation }\end{array}$ & Keterangan \\
\hline $\mathbf{0 , 3}$ & Valid \\
$<\mathbf{0 , 3}$ & Tidak Valid \\
\hline Sumber : Sugiyono, 2013 &
\end{tabular}

\section{Pengujian Reliabilitas}

Riduwan dan Sunarto (2007:348) Reliabilitas adalah suatu nilai yang menunjukan konsistensi suatu alat ukur dalam mengukur gejala yang sama dan sejauh mana hasil suatu pengukuran dapat dipercaya, artinya adalah sebuah konsistensi yang didapat dalam beberapa pelaksanaan pengukuran terhadap kelompok yang sama jika pengukuran diulang lebih dari sekali. Untuk menguji reliabilitas maka digunakan rumus Alpha Cronbach. Kriteria suatu instrumen penelitian dikatakan reliabel dengan teknik ini, yaitu apabila reliabilitas instrumen rhitung $\geq 0,6$.

Tabel 3 : Kriteria Uji Reliabilitas

\begin{tabular}{cc}
\hline Alpha Cronbach & Keterangan \\
\hline $\mathbf{2 0 , 6}$ & Reliabel \\
$<0,6$ & Tidak Reliabel \\
\hline Sumber : Sugiyono, 2007 &
\end{tabular}

\section{Uji Asumsi Klasik}

Sebelum melakukan pengujian hipotesis, terlebih dahulu dilakukan uji asumsi klasik yang mendasari dan menjadi persyaratan stastistik yang harus dipenuhi dalam penggunaan analisis regresi berganda yaitu koefisien regresi yang linier, tidak bias, konsisten, serta efisien. Uji asumsi klasik atas data primer maka dalam penelitian dilakukan uji normalitas, uji multikolonieritas, dan uji heteroskedastisitas.

\section{Metode Analisis Data}

Bentuk persamaan regresi yang dirumuskan berdasarkan hipotesis yang dikembangkan yaitu sebagai berikut (Nugroho, 2011:92) :

$$
\mathrm{Y}=\mathrm{a}+\beta_{1} \mathrm{X}_{1}+\beta_{2} \mathrm{X}_{2}+\beta_{3} \mathrm{X}_{3}+\beta_{4} \mathrm{X}_{4}+\varepsilon
$$

Dimana :

$\begin{array}{ll}\mathrm{Y} & =\text { Impementasi SAK EMKM } \\ \mathrm{a} & =\text { Nilai Konstanta } \\ \mathrm{X}_{1} & =\text { Sosialisasi SAK EMKM } \\ \mathrm{X}_{2} & =\text { Tingkat Pendidikan Pemilik } \\ \mathrm{X}_{3} & =\text { Persepsi Pelaku UMKM }\end{array}$


$\mathrm{X}_{4}=$ Pemahaman Akuntansi

$\varepsilon \quad=$ Error

$\beta_{1} \quad=$ Koefisien regresi variabel $\mathrm{X}_{1}$

$\beta_{2} \quad=$ Koefisien regresi variabel $\mathrm{X}_{2}$

$\beta_{3} \quad=$ Koefisien regresi variabel $\mathrm{X}_{3}$

$\beta_{4} \quad=$ Koefisien regresi variabel $\mathrm{X}_{4}$

\section{Uji Hipotesis}

\section{Uji Simultan (f-test)}

Semua variabel bebas yang mempunyai pengaruh atau tidak terhadap variabel terikat dapat diketahui dengan Uji F. Priyatno (2013:48) Uji statistik F atau uji koefisien regresi secara serentak, yaitu uji yang digunakan untuk mengetahui apakah terdapat pengaruh antara Sosialisasi SAK EMKM, Tingkat Pendidikan Pemilik, Persepsi Pelaku UMKM dan Pemahaman Akuntansi, secara bersama-sama atau secara simultan terhadap Implementasi SAK EMKM.

\section{Uji Parsial (t-test)}

Pengaruh variabel bebas secara individual terhadap variabel terikat dapat diketahui dengan melakukan uji t. Menurut Priyatno (2013:250) Uji t dimaksudkan untuk mengetahui pengaruh variabel independen terhadap variabel dependen secara individual atau secara parsial. Yang diuji dalam hal ini adalah signifikansi dan koefisiensi regresi. Pengambilan keputusan didapatkan berdasarkan perbandingan nilai $t$ hitung masing-masing koefisien regresi dengan nilai $\mathrm{t}$ tabel sesuai dengan $\alpha=0,05$.

\section{Koefisien Determinasi $\left(\mathbf{R}^{\mathbf{2}}\right)$}

Sugiyono (2012:257), Analisis koefisien determinasi (Rsquare $\mathrm{R}^{2}$ ) yaitu untuk mengetahui presentase kontribusi variabel Sosialisasi SAK EMKM, Tingkat Pendidikan Pemilik, Persepsi Pelaku UMKM dan Pemahaman Akuntansi secara simultan tidak mempunyai pengaruh terhadap variabel Implementasi SAK EMKM. Adapun rumus koefisien determinasi sebagai berikut :

$$
K D=r^{2} \times 100 \%
$$

\section{HASIL DAN PEMBAHASAN}

Salah satu bagian terpenting dari perekonomian suatu negara maupun daerah adalah UMKM. UMKM ini sangat memiliki peranan yang penting dalam keberlangsungan perekonomian masyarakat. UMKM melakukan penciptaan lapangan kerja baru yang menggunakan tenaga-tenaga unit rumah tangga yang sangat membantu negara atau pemerintah. Selain itu UMKM juga memiliki fleksibelitas yang tinggi jika dibandingkan dengan usaha yang berkapabilitas lebih besar. Bisnis yang terarah antara pelaku UMKM dengan elemen daya saing usaha sangat perlu perhatian yang khusus dan didukung oleh informasi yang akurat untuk UMKM. Dalam UU No. 20 Tahun 2008 Bab III pasal V yang berisikan tentang peningkatan peran usaha mikro kecil dan menengah dalam membangun daerah, menciptakan lapangan pekerjaan, pemerataan pendapatan, pertumbuhan ekonomi dan pengentasan kemiskinan, hal tersebut menjelaskan bahwa UMKM memiliki peran strategis dalam pendapatan nasional dan pengurangan pengangguran. Sampel penelitiannya adalah UMKM Kota Bogor yang berjumlah 96 pemilik UMKM. Pemilik UMKM yang menjadi sampel dalam penelitian disajikan dalam Tabel 4:

Tabel 4 Rekapitulasi Karakteistik Responden

\begin{tabular}{cccc}
\hline No & $\begin{array}{c}\text { Kriteria } \\
\text { Responden }\end{array}$ & Karakteristik & $\begin{array}{c}\text { Jumlah/or } \\
\text { ang }\end{array}$ \\
\hline $\mathbf{1}$ & Jenis Kelamin & Perempuan & $56(58 \%)$ \\
$\mathbf{2}$ & Usia & $31-40 \mathrm{Th}$ & $46(48 \%)$ \\
$\mathbf{3}$ & Tingkat & SMA/SMK/MA/ & $72(75 \%)$ \\
& Pendidikan & Sederajat & \\
$\mathbf{4}$ & Lama Usaha & $1-3$ Tahun & $40(42 \%)$ \\
$\mathbf{5}$ & Omset Usaha & Rp. 10,1 - 25 juta & $40(42 \%)$ \\
$\mathbf{6}$ & Laporan & $>3$ Th & $38(40 \%)$ \\
& Keuangan & & \\
\hline
\end{tabular}

Sumber: Data diolah,2017

Berdasarkan Tabel 4 menunjukan bahwa karakteristik responden dalam penelitian ini yaitu didominasi oleh perempuan sebanyak 56 orang, dengan usia responden berkisar antara $31-40$ tahun dengan tingkat pendidikan berasal dari SMA/SMK/MA/Sederajat dengan lama usaha sekitar $1-3$ tahun yang rata-rata memiliki omset Rp. 10,1 - 25 juta perbulan. Namun dalam usaha yang membuat/menyusun laporan keuangan didominasi oleh yang menyusun > 3 tahun. Berdasarkan karakteristik tersebut dapat disimpulkan bahwa pemilik usaha yang ada di Kota Bogor 
berada pada rentang waktu produktif dengan mayoritas pendidikan yang setara dan rentang waktu yang dapat dikatakan masih singkat namun memiliki omset dan membuat/menyusun laporan keuangan.

\section{Sosialisasi SAK EMKM}

Rekapitulasi skor tanggapan mengenai sosialisasi SAK EMKM terdapat pada Tabel 5:

Tabel 5 Rekapitulasi Skor Tanggapan Variabel Sosialisasi SAK EMKM

\begin{tabular}{|c|c|c|c|}
\hline No & Pernyataan & Jawaban & Ket \\
\hline 1 & $\begin{array}{l}\text { Sosialisasi standar akuntansi } \\
\text { keuangan dilakukan melalui } \\
\text { seminar atau pelatihan } \\
\text { akuntansi }\end{array}$ & 4,11 & Setuju \\
\hline 2 & $\begin{array}{l}\text { Sosialisasi standar akuntansi } \\
\text { keuangan dilakukan secara } \\
\text { rutin oleh Dinas Koperasi } \\
\text { dan UMKM }\end{array}$ & 3,77 & Setuju \\
\hline 3 & $\begin{array}{l}\text { Sosialisasi dilakukan untuk } \\
\text { membuat/menyusun laporan } \\
\text { keuangan sesuai standar } \\
\text { akuntansi dan } \\
\text { Peraturan/Undang-Undang } \\
\text { yang berlaku }\end{array}$ & 4,04 & Setuju \\
\hline 4 & $\begin{array}{l}\text { Sosialisasi dilakukan untuk } \\
\text { mengetahui informasi } \\
\text { terbaru mengenai standar } \\
\text { akuntansi keuangan yang } \\
\text { berlaku }\end{array}$ & 4,06 & Setuju \\
\hline 5 & $\begin{array}{l}\text { Sosialisasi standar akuntansi } \\
\text { keuangan memberikan } \\
\text { pengetahuan } \\
\text { pemahaman tentang laporan } \\
\text { keuangan }\end{array}$ & 4,10 & Setuju \\
\hline 6 & $\begin{array}{l}\text { Sosialisasi standar akuntansi } \\
\text { keuangan dapat diterima } \\
\text { melalui media, seperti: } \\
\text { internet, tv, dan lain-lain } \\
\text { Total }\end{array}$ & 3,98 & Setuju \\
\hline & Nilai Rata-Rata & 4,01 & Setuju \\
\hline
\end{tabular}

\section{Tingkat Pendidikan Pemilik}

Rekapitulasi skor tanggapan tingkat pendidikan pemilik terdapat pada Tabel 6:

Tabel 6 : Rekapitulasi Skor Tanggapan Variabel Tingkat Pendidikan Pemilik

\begin{tabular}{|c|c|c|c|}
\hline No & Pernyataan & Jawaban & Ket \\
\hline 1 & $\begin{array}{l}\text { Tingkat pendidikan } \\
\text { menambah pengetahuan } \\
\text { akuntansi melalui pendidikan } \\
\text { formal seperti SMA/MA } \\
\text { jurusan IPS dan SMK jurusan } \\
\text { akuntansi }\end{array}$ & 4,30 & $\begin{array}{l}\text { Sangat } \\
\text { Setuju }\end{array}$ \\
\hline 2 & $\begin{array}{lr}\text { Tingkat } & \text { pendidikan } \\
\text { menambah } & \text { pengetahuan } \\
\text { akuntansi melalui pendidikan }\end{array}$ & 4,54 & $\begin{array}{l}\text { Sangat } \\
\text { Setuju }\end{array}$ \\
\hline
\end{tabular}

\begin{tabular}{|c|c|c|c|}
\hline \multirow{3}{*}{3} & formal seperti Perguruan & & \\
\hline & $\begin{array}{l}\text { Tinggi jurusan akuntansi } \\
\text { Tingkat pengetahuan }\end{array}$ & & \\
\hline & $\begin{array}{l}\text { akuntansi bisa didapatkan } \\
\text { melalui pendidikan non } \\
\text { formal, seperti pelatihan dan } \\
\text { seminar }\end{array}$ & 4,06 & Setuju \\
\hline \multirow[t]{4}{*}{4} & $\begin{array}{l}\text { Tingkat pengetahuan } \\
\text { akuntansi bisa didapatkan }\end{array}$ & & \\
\hline & $\begin{array}{l}\text { melalui pendidikan non } \\
\text { formal seperti khursus }\end{array}$ & 4,02 & setuju \\
\hline & Total & 16,92 & \\
\hline & Nilai Rata-Rata & 4,23 & $\begin{array}{l}\text { Sanga } \\
\text { Setuju }\end{array}$ \\
\hline
\end{tabular}

\section{Persepsi Pelaku UMKM}

Rekapitulasi skor tanggapan mengenai persepsi pelaku UMKM terdapat pada Tabel 7 :

Tabel 7 : Rekapitulasi Skor Tanggapan Variabel Persepsi Pelaku UMKM

\begin{tabular}{|c|c|c|c|}
\hline No & Pernyataan & Jawaban & Ket \\
\hline 1 & 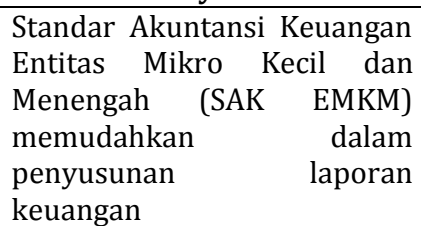 & 4,13 & Setuju \\
\hline 2 & $\begin{array}{l}\text { Standar Akuntansi Keuangan } \\
\text { Entitas Mikro Kecil dan } \\
\text { Menengah (SAK EMKM) } \\
\text { memudahkan r dalam } \\
\text { mengevaluasi, pengendalian } \\
\text { atau pengawasan dan } \\
\text { pelaporan } \\
\text { akuntansi }\end{array}$ & 4,11 & Setuju \\
\hline 3 & $\begin{array}{l}\text { Penerapan Standar Akuntansi } \\
\text { Keuangan Entitas Mikro Kecil } \\
\text { dan Menengah (SAK EMKM) } \\
\text { menghasilkan informasi yang } \\
\text { bermanfaat bagi sarana } \\
\text { pengambilan keputusan }\end{array}$ & 3,91 & Setuju \\
\hline 4 & $\begin{array}{l}\text { Dengan menerapkan Standar } \\
\text { Akuntansi Keuangan Entitas } \\
\text { Mikro kecil Menengah (SAK } \\
\text { EMKM) dapat memudahkan } \\
\text { untuk melakukan pinjaman } \\
\text { pada lembaga keuangan }\end{array}$ & 3,93 & Setuju \\
\hline 5 & $\begin{array}{l}\text { Penerapan Standar Akuntansi } \\
\text { Keuangan Entitas Mikro Kecil } \\
\text { dan Menengah (SAK EMKM) } \\
\text { memudahkan pengusaha } \\
\text { untuk mendapatkan investor }\end{array}$ & 3,94 & Setuju \\
\hline 6 & $\begin{array}{l}\text { Dengan menerapkan Standar } \\
\text { Akuntansi Keuangan Entitas } \\
\text { Mikro Kecil dan Menengah } \\
\text { (SAK EMKM) dapat } \\
\text { menghasilkan informasi } \\
\text { mengenai kekayaan dan } \\
\text { kinerja perusahaan } \\
\quad \text { Total } \\
\text { Nilai Rata-Rata }\end{array}$ & $\begin{array}{c}24,34 \\
4,06\end{array}$ & $\begin{array}{l}\text { Sangat } \\
\text { Setuju }\end{array}$ \\
\hline
\end{tabular}

Sumber: Data diolah,2017

Pemahaman Akuntansi 
Rekapitulasi skor tanggapan mengenai pemahaman akuntansi terdapat pada Tabel 8 :

Tabel 8 : Rekapitulasi Skor Tanggapan Variabel Pemahaman Akuntansi

\begin{tabular}{|c|c|c|c|}
\hline No & Pernyataan & Jawaban & Ket \\
\hline 1 & $\begin{array}{l}\text { Saya memahami transaksi } \\
\text { akuntansi dalam usaha yang } \\
\text { saya jalankan }\end{array}$ & 4,27 & $\begin{array}{l}\text { Sangat } \\
\text { Setuju }\end{array}$ \\
\hline 2 & $\begin{array}{l}\text { Adanya dokumentasi dari } \\
\text { setiap transaksi yang terjadi } \\
\text { sebagai perekam data } \\
\text { akuntansi usaha saya }\end{array}$ & 4,42 & $\begin{array}{l}\text { Sangat } \\
\text { Setuju }\end{array}$ \\
\hline 3 & $\begin{array}{l}\text { Saya memahami tahapan } \\
\text { kegiatan akuntansi dalam } \\
\text { pembuatan laporan keuangan }\end{array}$ & 4,25 & $\begin{array}{l}\text { Sangat } \\
\text { Setuju }\end{array}$ \\
\hline 4 & $\begin{array}{l}\text { Saya memahami pencatatan } \\
\text { akuntansi } \\
\text { akuntansi }\end{array}$ & 3,92 & Setuju \\
\hline 5 & $\begin{array}{l}\text { Saya memahami penyusunan } \\
\text { laporan keuangan }\end{array}$ & 4,21 & $\begin{array}{l}\text { Sangat } \\
\text { Setuju }\end{array}$ \\
\hline 6 & $\begin{array}{l}\text { Saya dapat membuat laporan } \\
\text { keuangan sesuai standar } \\
\text { akuntansi }\end{array}$ & 3,81 & Setuju \\
\hline & $\begin{array}{c}\text { Total } \\
\text { Nilai Rata-Rata }\end{array}$ & $\begin{array}{c}24,88 \\
4,15\end{array}$ & Setuju \\
\hline
\end{tabular}

Sumber: Data diolah,2017

\section{Implementasi SAK EMKM}

Rekapitulasi skor tanggapan mengenai implementasi SAK EMKM terdapat pada Tabel 9:

Tabel 9 Rekapitulasi Skor Tanggapan Variabel Implementasi SAK EMKM

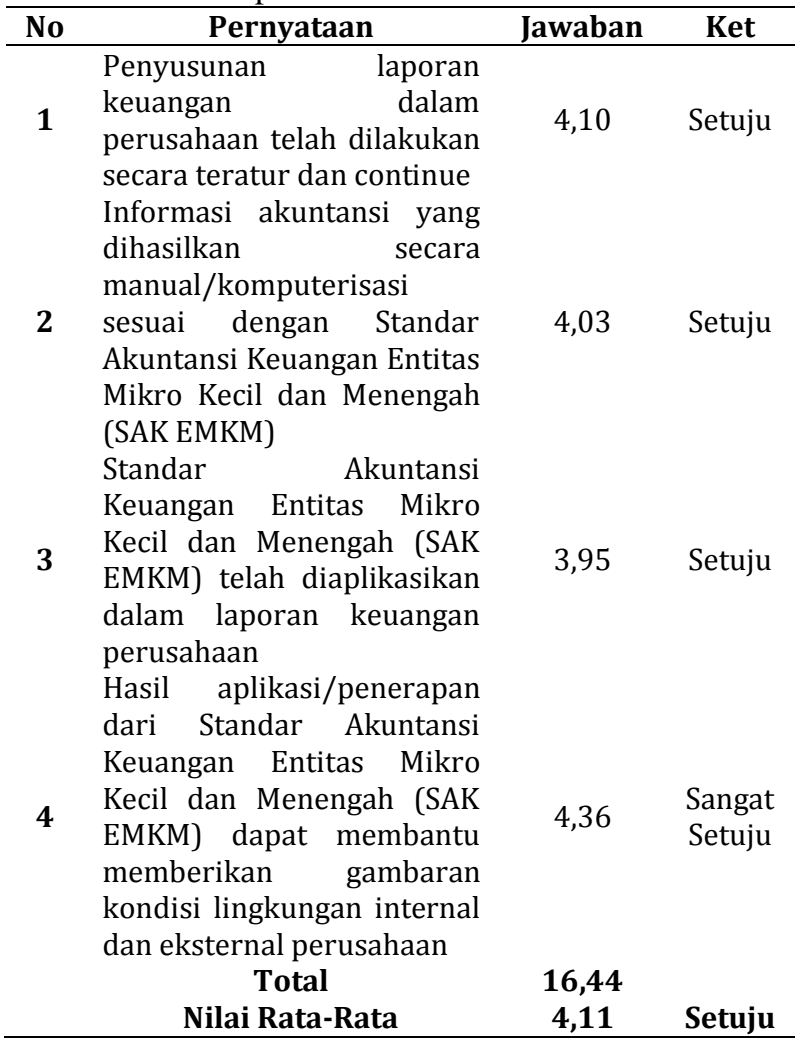

Sumber: Data diolah,2017

\section{Pengujian Instrumen Uji Validitas}

Uji validitas bertujuan untuk mengetahui sejauh mana ketepatan alat ukur atau instrumen yang digunakan dapat mengukur apa yang seharusnya diukur. Instrumen dikatakan valid ketika alat ukur yang digunakan untuk mendapatkan data penelitian sudah tepat. Uji validitas dilakukan dengan menghitung korelasi antar masingmasing butir pernyataan dengan skor total pada masing-masing variabel. Nilai tersebut kemudian dibandingkan dengan nilai $r_{\text {kritis }}$. Hasil uji validitas variabel sosialisasi SAK EMKM $\left(\mathrm{X}_{1}\right)$, tingkat pendidikan pemilik $\left(\mathrm{X}_{2}\right)$, persepsi pelaku UMKM $\left(\mathrm{X}_{3}\right)$, pemahaman akuntansi $\left(\mathrm{X}_{4}\right)$ dan variabel implementasi SAK EMKM (Y) diuraikan pada Tabel 10 :

Tabel 10 : Hasil Uji Validitas

\begin{tabular}{ccccc}
\hline No & Variabel & $\mathbf{r}_{\text {hitung }}$ & $\mathbf{r}_{\text {kritis }}$ & Ket \\
\hline 1 & Sosialisasi SAK EMKM & 0,479 & 0,3 & Valid \\
2 & Tingkat Pendidikan & 0,510 & 0,3 & Valid \\
& Pemilik & & & \\
3 & Persepsi Pelaku UMKM & 0,652 & 0,3 & Valid \\
4 & Pemahaman Akuntansi & 0,862 & 0,3 & Valid \\
5 & Implementasi SAK & 0,865 & 0,3 & Valid \\
& EMKM & & &
\end{tabular}

Sumber: Output pengolahan data dengan SPSS 22,2017

Berdasarkan nilai tersebut ditentukan nilai standar (r-kritis) adalah sebesar 0,3 hal tersebut senada dengan yang disampaikan oleh Sugiyono (2013:182) yang menjelaskan bahwa ketika nilai hitung besarnya lebih dari atau sama dengan 0,3 maka data tersebut valid. Semua pernyataan dari variabel independen (sosialisasi SAK EMKM, tingkat pendidikan pemilik, persepsi pelaku UMKM dan pemahaman akuntansi) dan variabel dependen yaitu implementasi SAK EMKM dinyatakan valid karena $r_{\text {hitung }}$ masing-masing pernyataan lebih besar dari $r_{\text {kritis. }}$.

\section{Uji Reliabilitas}

Uji reliabilitas dilakukan untuk mengetahui apakah alat yang digunakan menunjukan tingkat ketepatan, keakuratan, kestabilan dan konsistensi alat tersebut, dan hasil pengukuran tersebut akan tetap konsisten bila dilakukan pengukuran kembali. Untuk mengukur konsistensi interval penggunaan instrumen digunakan Cronbach Alpha, untuk mengetahui bahwa semua 
variabel dikatakan reliabel, rata-rata nilai Cronbach Alpha harus lebih besar dari atau sama dengan 0,6 . Hasil pengujian reliabilitas diuraikan pada Tabel 11:

Tabel 11 : Hasil Uji Reliabilitas

\begin{tabular}{ccccc}
\hline No & Variabel & $\begin{array}{c}\text { Cronbach's } \\
\text { Alpha }\end{array}$ & r $_{\text {kritis }}$ & Ket \\
\hline 1 & $\begin{array}{c}\text { Sosialisasi SAK } \\
\text { EMKM }\end{array}$ & 0,820 & 0,6 & Reliabel \\
2 & $\begin{array}{c}\text { Tingkat } \\
\text { Pendidikan } \\
\text { Pemilik }\end{array}$ & 0,819 & 0,6 & Reliabel \\
3 & $\begin{array}{c}\text { Persepsi Pelaku } \\
\text { UMKM }\end{array}$ & 0,816 & 0,6 & Reliabel \\
4 & $\begin{array}{c}\text { Pemahaman } \\
\text { Akuntansi } \\
\text { Implementasi } \\
\text { SAK EMKM }\end{array}$ & 0,802 & 0,6 & Reliabel \\
\hline
\end{tabular}

Sumber: Output pengolahan data dengan SPSS 22,2017

Berdasarkan nilai tersebut ditentukan nilai standar (r-kritis) adalah sebesar 0,6 hal tersebut senada dengan yang disampaikan oleh Sugiyono (2013:184) yang menjelaskan bahwa suatu instrumen dinyatakan reliabel bila koefisien lebih dari atau sama dengan 0,6 . Semua pernyataan dari variabel independen (sosialisasi SAK EMKM, tingkat pendidikan pemilik, persepsi pelaku UMKM dan pemahaman akuntansi) dan variabel dependen yaitu implementasi SAK EMKM dinyatakan reliabel karena Cronbach's Alplha masing-masing pernyataan lebih besar dari $\mathrm{r}_{\text {kritis. }}$

\section{Hasil Analisa dan Pembahasan Analisa Regresi Berganda}

Analisis regresi linier berganda digunakan untuk mengetahui hubungan fungsional antara beberapa variabel bebas secara bersama-sama terhadap variabel terikat, dan juga mengetahui jika variabel independen dinaikan atau diturunkan nilainya. Hasil tersebut dapat dilihat pada Tabel 12 :

Tabel 12: Analisis Regresi Linier Berganda Coefficients $^{\mathrm{a}}$

\begin{tabular}{|c|c|c|c|c|c|}
\hline \multirow[t]{2}{*}{ Model } & \multicolumn{2}{|c|}{$\begin{array}{l}\text { Unstandardized } \\
\text { Coefficients }\end{array}$} & \multirow{2}{*}{$\begin{array}{c}\text { Standardized } \\
\text { Coefficients }\end{array}$} & \multirow[t]{2}{*}{$T$} & \multirow[t]{2}{*}{ Sig. } \\
\hline & B & $\begin{array}{l}\text { Std. } \\
\text { Error }\end{array}$ & & & \\
\hline 1 (Constant) & $-7,285$ & 2,886 & & $\begin{array}{r}- \\
2,524\end{array}$ & 013 \\
\hline $\mathrm{X}_{1}$ & 234 & ,084 & 200 & 2,784 & ,007 \\
\hline$x_{2}$ & ,265 & ,091 & 216 & 2,921 & ,004 \\
\hline$x_{3}$ & 196 & ,096 & 159 & 2,036 & ,045 \\
\hline$X_{4}$ & ,355 & ,059 & ,501 & 6,041 &, 000 \\
\hline
\end{tabular}

a. Dependent Variable: Implementasi SAK EMKM

Sumber: Output pengolahan data dengan SPSS 22, 2017

Berdasarkan Tabel 12 diketahui bahwa nilai persamaan regresi yaitu sebagai berikut: $\mathrm{Y}=\mathrm{a}+\beta_{1} \mathrm{X}_{1}+\beta_{2} \mathrm{X}_{2}+\beta_{3} \mathrm{X}_{3}+\beta_{4} \mathrm{X}_{4}+\varepsilon$ $\mathrm{Y}=-7,285+0,234 \mathrm{X}_{1}+0,265 \mathrm{X}_{2}+0,196 \mathrm{X}_{3}+$ $0,355 \mathrm{X}_{4}+\varepsilon$

Interpretasi dari regresi tersebut adalah sebagai berikut:

1. Hasil persamaan regresi tersebut diperoleh nilai konstanta sebesar -7,285, nilai tersebut mempunyai arti bahwa jika seluruh variabel bebas yaitu sosialisasi SAK EMKM, tingkat pendidikan pemilik, persepsi pelaku UMKM dan pemahaman akuntansi bernilai 0, maka implementasi SAK EMKM berkurang atau mengalami penurunan sebesar 7,285.

2. Hasil persamaan regresi untuk variabel sosialisasi SAK EMKM sebesar 0,234. Hal tersebut menunjukan bahwa untuk setiap peningkatan sosialisasi SAK EMKM sebesar $100 \%$, dengan asumsi variabel tingkat pendidikan pemilik, persepsi pelaku UMKM dan pemahaman akuntansi bernilai 0 , maka menyebabkan meningkatnya implementasi SAK EMKM sebesar 0,234 (23,4\%).

3. Hasil persamaan regresi untuk variabel tingkat pendidikan pemilik sebesar 0,265. Hal tersebut menunjukan bahwa untuk setiap peningkatan tingkat pendidikan pemilik sebesar $100 \%$, dengan asumsi variabel sosialisasi SAK EMKM, persepsi pelaku UMKM dan pemahaman akuntansi bernilai 0 , maka menyebabkan meningkatnya implementasi SAK EMKM sebesar 0,265 (26,5\%).

4. Hasil persamaan regresi untuk variabel persepsi pelaku UMKM sebesar 0,196. Hal tersebut menunjukan bahwa untuk setiap peningkatan persepsi pelaku UMKM sebesar $100 \%$, dengan asumsi variabel sosialisasi SAK EMKM, tingkat pendidikan pemilik dan pemahaman akuntansi bernilai 0 , maka menyebabkan meningkatnya implementasi SAK EMKM sebesar 0,196 (19,6\%).

5. Hasil persamaan regresi untuk variabel pemahaman akuntansi sebesar 0,355. Hal tersebut menunjukan bahwa untuk setiap 
peningkatan pemahaman akuntansi sebesar $100 \%$, dengan asumsi variabel sosialisasi SAK EMKM, tingkat pendidikan pemilik dan persepsi pelaku UMKM bernilai 0 , maka menyebabkan meningkatnya implementasi SAK EMKM sebesar 0,355 (35,5\%).

Berdasarkan hasil tersebut bahwa pemahaman akuntansi $\left(\mathrm{X}_{4}\right)$ merupakan variabel yang memiliki pengaruh paling dominan karena memiliki nilai koefisien regresi sebesar 0,355 atau $35,5 \%$, artinya pemahaman akuntansi dari para pemilik usaha sangat mempengaruhi implementasi SAK EMKM sebesar 35,5\% pada penyusunan laporan keuangan usaha.

\section{Pengujian Hipotesis}

Pengujian ini dilakukan untuk mengetahui pengaruh secara simultan sosialisasi SAK EMKM, tingkat pendidikan pemilik, persepsi pelaku UMKM dan pemahaman akuntansi terhadap implementasi SAK EMKM. Kriteria ditentukan dalam uji $F$ ini yaitu jika $\mathrm{F}_{\text {hitung }}>\mathrm{F}_{\text {tabel }}$ maka $\mathrm{H}_{\mathrm{o}}$ ditolak dan $\mathrm{H}_{\mathrm{a}}$ diterima, sedangkan jika $\mathrm{F}_{\text {hitung }} \leq \mathrm{F}_{\text {tabel }}$ maka $\mathrm{H}_{\mathrm{o}}$ diterima dan $\mathrm{H}_{\mathrm{a}}$ ditolak. Hipotesis yang digunakan yaitu sebagai berikut:

$\mathrm{H}_{\mathrm{o}}: \beta_{1}, \beta_{2}, \beta_{3}, \beta_{4}=0$ : Sosialisasi

EMKM,

Pendidikan

SAK

Tingkat

Persepsi Pelaku UMKM

dan Pemahaman

Akuntansi secara

simultan tidak

mempunyai pengaruh

terhadap variabel

Implementasi SAK

EMKM.

$\mathrm{H}_{\mathrm{a}}: \beta_{1}, \beta_{2}, \beta_{3}, \beta_{4} \neq 0$ : Sosialisasi

EMKM,

SAK

Pendidikan

Tingkat

Persepsi Pelaku UMKM

dan Pemahaman

Akuntansi secara

simultan mempunyai

pengaruh terhadap

variabel Implementasi

SAK EMKM.
Hasil uji $F$ dapat diperoleh melalui Tabel analisis varians (Anova) seperti yang terlihat pada Tabel 13 :

Tabel 13 : Uji F

ANOVA $^{\mathrm{a}}$

\begin{tabular}{|c|c|c|c|c|c|}
\hline \multirow[b]{2}{*}{ Model } & \multicolumn{4}{|l|}{ 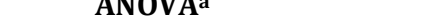 } & \multirow[b]{2}{*}{ Sig. } \\
\hline & $\begin{array}{l}\text { Sum of } \\
\text { Squares }\end{array}$ & $\mathrm{Df}$ & $\begin{array}{l}\text { Mean } \\
\text { Square }\end{array}$ & $\mathrm{F}$ & \\
\hline 1 Regression & 171,260 & 4 & 42,815 & 30,833 &, $000^{\mathrm{b}}$ \\
\hline Residual & 126,365 & 91 & 1,389 & & \\
\hline Total & 297,625 & 95 & & & \\
\hline
\end{tabular}

a. Dependent Variable: Implementasi SAK EMKM

b. Predictors: (Constant), Pemahaman Akuntansi,

Sosialisasi SAK EMKM, Tingkat Pendidikan Pemilik,

Persepsi Pelaku UMKM

Sumber: Output pengolahan data dengan SPSS 22, 2017

Berdasarkan Tabel 13 dapat diketahui bahwa hasil pengujian menggunakan uji $\mathrm{F}$, diperoleh nilai $F_{\text {hitung }}$ sebesar 30,833, sedangkan nilai $F_{\text {tabel }}$ sebesar 2,471. Apabila $\mathrm{F}_{\text {hitung }}$ dibandingkan dengan $\mathrm{F}_{\text {tabel }}$ maka $\mathrm{F}_{\text {hitung }}$ $>\mathrm{F}_{\text {tabel }}(30,833>2,471)$ dengan nilai signifikansi $F$ sebesar $0,00<0,05$. Hal ini berarti bahwa Ho ditolak dan Ha diterima. Kondisi ini bermakna bahwa sosialisasi SAK EMKM, tingkat pendidikan pemilik, persepsi pelaku UMKM dan pemahaman akuntansi secara simultan berpengaruh positif dan signifikan terhadap implementasi SAK EMKM pada UMKM di Kota Bogor.

Berdasarkan hasil uji $\mathrm{F}$ menunjukan bahwa jika pihak-pihak tertentu seperti pemerintah melakukan sosialisasi SAK EMKM kepada pemilik UMKM maka implementasi SAK EMKM akan baik, karena pentingnya dilakukan sosialisasi bagi pelaku UMKM untuk meningkatkan kualitas laporan keuangan yang dibuat. Sehingga pelaku UMKM akan dengan mudah dapat melakukan peminjaman modal ke lembaga keuangan baik bank maupun non bank, karena laporan keuangan adalah salah satu syarat dalam pengajuan pinjaman yang harus dipenuhi oleh pelaku UMKM dalam melakukan pinjaman modal. Pentingnya tingkat pendidikan pemilik yang dimiliki mempengaruhi dalam pengimplementasian standar akuntansi karena pendidikan dan kemampuan penting dimiliki oleh pemilik usaha. Jika persepsi pelaku UMKM juga baik maka implementasi SAK EMKM pada usaha dapat dilakukan. Begitu pula dengan pemahaman akuntansi, pemahaman pemilik tentang akuntansi baik, maka terhadap implementasi standar akuntansi dalam 
penyusunan laporan keuangan pula akan baik dan memudahkan usaha tersebut. Selain untuk peminjaman modal juga laporan keuangan sesuai SAK juga memudahkan pengusaha mengetahui kinerja dan kekayaan usaha tersebut, juga dapat memudahkan untuk mendatangkan investor. Implementasi laporan keuangan sesuai SAK bukan hanya sekedar aktivitas, tetapi suatu yang terencana dan untuk mencapai tujuan kegiatan. Hal ini sejalan dengan teori yang menyebutkan bahwa suatu aktivitas, aksi, tindakan maupun adanya mekanisme untuk suatu system yang terencana dan bermanfaat dalam suati kegiatan merupakan sebuah implementasi (Usman, 2002:70).

Hasil penelitian ini mendukung penelitian yang dilakukan oleh Dewi, Yuniarta dan Wahyuni (2017) dan Meidiyustiani (2016) yang menyatakan bahwa sosialisasi SAK ETAP kepada pemilik UMKM, tingkat pendidikan pemilik yang dimiliki baik, persepsi pelaku UMKM baik dan pemahaman pelaku UMKM juga baik maka implementasi SAK EMKM pada UMKM di Kota Bogor dapat dilakukan.

\section{Uji t}

Pengujian ini dilakukan untuk mengetahui pengaruh secara parsial sosialisasi SAK EMKM, tingkat pendidikan pemilik, persepsi pelaku UMKM dan pemahaman akuntansi terhadap implementasi SAK EMKM. Berdasarkan perhitungan diperoleh hasil berikut ini :

Tabel 14 Uji t

Coefficients $^{\mathrm{a}}$

\begin{tabular}{|c|c|c|c|c|c|}
\hline \multirow[t]{2}{*}{ Model } & \multicolumn{2}{|c|}{$\begin{array}{c}\text { Unstandardized } \\
\text { Coefficients }\end{array}$} & \multirow{2}{*}{$\begin{array}{c}\begin{array}{c}\text { Standardized } \\
\text { Coefficients }\end{array} \\
\text { Beta }\end{array}$} & \multirow[t]{2}{*}{$\mathrm{T}$} & \multirow[t]{2}{*}{ Sig. } \\
\hline & $B$ & $\begin{array}{l}\text { Std. } \\
\text { Error }\end{array}$ & & & \\
\hline \multirow[t]{2}{*}{1 (Constant) } & $-7,285$ & 2,886 & & - & ,013 \\
\hline & & & & 2,524 & \\
\hline $\mathrm{X}_{1}$ & ,234 & ,084 & 200 & 2,784 & ,007 \\
\hline $\mathrm{X}_{2}$ & 265 & 091 & 216 & 2,921 & ,004 \\
\hline $\mathrm{X}_{3}$ & 196 & ,096 & 159 & 2,036 & ,045 \\
\hline $\mathrm{X}_{4}$ & ,355 & ,059 & ,501 & 6,041 & ,000 \\
\hline
\end{tabular}

\section{Sosialisasi SAK EMKM}

Untuk mengetahui ada atau tidaknya pengaruh sosialisasi SAK EMKM terhadap implementasi SAK EMKM, secara statistik akan diuji hipotesis sebagai berikut:

$\mathrm{H}_{\mathrm{o}}: \beta_{1}=0$; Sosialisasi SAK EMKM tidak berpengaruh terhadap Implementasi SAK EMKM.
$\mathrm{H}_{\mathrm{a}}: \beta_{1} \neq 0$; Sosialisasi $\quad$ SAK EMKM berpengaruh terhadap Implementasi SAK EMKM.

Hasil pengujian parsial diperoleh nilai $\mathrm{t}_{\text {hitung }}$ untuk sosialisasi SAK EMKM sebesar 2,784, sedangkan nilai $t_{\text {tabel }}$ sebesar 1,986. Apabila $t_{\text {hitung }}$ dibandingkan dengan $t_{\text {tabel }}$ maka $t_{\text {hitung }}>t_{\text {tabel }}(2,784>1,986)$ dengan tingkat signifikan $0,007<0,05$. Hal ini berarti bahwa Ho ditolak dan $\mathrm{Ha}$ diterima. Kondisi ini bermakna bahwa sosialisasi SAK EMKM secara parsial berpengaruh positif terhadap implementasi SAK EMKM pada UMKM di Kota Bogor.

Sosialisasi SAK EMKM merupakan pemberian informasi atau pelatihan terkait SAK EMKM oleh pihak-pihak terkait yang dapat memberikan sosialisasi SAK EMKM (Seperti Dinas Koperasi dan UMKM Kota Bogor). Pentingnya dilakukan sosialisasi bagi pelaku UMKM untuk menambah pengetahuan dan dapat memotivasi pemilik/ manajer untuk meningkatkan kualitas laporan keuangan yang dibuat. Sehingga pelaku UMKM akan dengan mudah dapat melakukan peminjaman modal ke lembaga keuangan untuk pinjaman modal. Hasil penelitian ini mendukung penelitian yang dilakukan oleh Dewi, Yuniarta dan Wahyuni (2017) dan teori tujuan sosialisasi menurut Cohen yang menyebutkan bahwa sosialisasi bertujuan agar tiap individu mendapat bekal keterampilan serta membentuk sistem perilaku.

\section{Tingkat Pendidikan Pemilik}

Untuk mengetahui ada atau tidaknya pengaruh tingkat pendidikan pemilik terhadap implementasi SAK EMKM, secara statistik akan diuji hipotesis sebagai berikut:

$\mathrm{H}_{\mathrm{o}}: \beta_{2}=0$ : Tingkat Pendidikan Pemilik tidak berpengaruh terhadap Implementasi SAK EMKM.

$\mathrm{H}_{\mathrm{a}}: \beta_{2} \neq 0$ : Tingkat Pendidikan Pemilik berpengaruh terhadap Implementasi SAK EMKM. 
Hasil parsial diperoleh nilai $t_{\text {hitung }}$ untuk tingkat pendidikan pemilik sebesar 2,921, sedangkan nilai $t_{\text {tabel }}$ sebesar 1,986. Apabila $t_{\text {hitung }}$ dibandingkan dengan $t_{\text {tabel }}$ maka $t_{\text {hitung }}>t_{\text {tabel }}(2,921>1,986)$ dengan tingkat signifikan $0,004<0,05$. Hal ini berarti bahwa Ho ditolak dan Ha diterima. Kondisi ini bermakna bahwa tingkat pendidikan pemilik secara parsial berpengaruh positif terhadap implementasi SAK EMKM pada UMKM di Kota Bogor.

Tingkat pendidikan pemilik merupakan pendidikan terakhir baik formal maupun non formal yang dimiliki pemilik UMKM, pendidikan formal maupun non formal pemilik UMKM dapat berpengaruh terhadap pengetahuan akuntansi karena materi akuntansi didapatkan pada jenjang pendidikan yang lebih tinggi dengan melatarkan jurusan yang sama. Pendidikan berpengaruh terhadap peningkatan kemampuan menyerap dari pengetahuan baru. Keberhasilan seorang pemilik usaha juga tergantung pada pendidikan dan kemampuan belajarnya dalam lingkungan usaha tersebut, pemilik usaha dituntut untuk mengerti akan apa yang karyawan kerjakan, maka dari itu pendidikan dianggap penting. Hasil penelitian ini mendukung penelitian yang dilakukan oleh Dewi, Yuniarta dan Wahyuni (2017) dan teori Muniarti (2002:138) menyebutkan bahwa pendidikan yang pernah ditempuh sangat menentukan keahlian dan kemampuan pemilik atau manajer perusahaan kecil dan menengah.

\section{Persepsi Pelaku UMKM}

Untuk mengetahui ada atau tidaknya pengaruh persepsi pelaku UMKM terhadap implementasi SAK EMKM, secara statistik akan diuji hipotesis sebagai berikut:

$$
\begin{aligned}
& \mathrm{H}_{\mathrm{o}}: \beta_{3}=0 \text { : Persepsi Pelaku UMKM tidak } \\
& \text { berpengaruh terhadap } \\
& \text { Implementasi SAK EMKM. }
\end{aligned}
$$

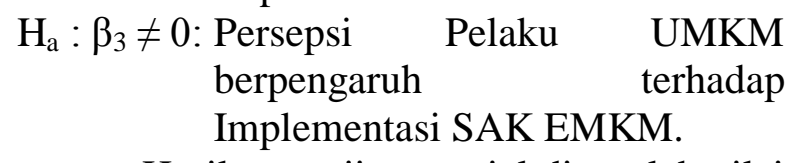

Hasil pengujian parsial diperoleh nilai $\mathfrak{t}_{\text {hitung }}$ untuk persepsi pelaku UMKM sebesar 2,036, sedangkan nilai $t_{\text {tabel }}$ sebesar 1,986 . Apabila $t_{\text {hitung }}$ dibandingkan dengan $t_{\text {tabel }}$ maka $t_{\text {hitung }}>t_{\text {tabel }}(2,036>1,986)$ dengan tingkat signifikan $0,045<0,05$. Hal ini berarti bahwa Ho ditolak dan Ha diterima. Kondisi ini bermakna bahwa persepsi pelaku UMKM secara parsial berpengaruh positif terhadap implementasi SAK EMKM pada UMKM di Kota Bogor.

Persepsi adalah bagaimana orang melihat atau menginterpretasikan suatu objek maupun peristiwa. Perlunya sosialisasi dari pihak-pihak terkait seperti pemerintah untuk memperkenalkan SAK EMKM dan mengubah persepsi para pengusaha UMKM agar dapat membuat/menyusun laporan keuangan sesuai dengan SAK. Dimana dengan adanya persepsi yang baik maka dapat menjadikan persepsi tersebut sebagai penerimaan dan evaluasi untuk menjadikan usaha lebih baik dari sebelumnya. Hasil penelitian ini mendukung penelitian yang dilakukan oleh Dewi, Yuniarta dan Wahyuni (2017) dan teori Robbin (2003:124) yang mengemukakan bahwa indikator persepsi ada dua macam yaitu penerimaan dan evaluasi. Penerimaan merupakan proses terjadinya persepsi dalam tahap fisiologis, artinya menangkap rangsangan dari luar. Evaluasi langkah individu setelah menerima rangsangan dari luar. Evaluasi bersifat subjektif karena dapat menilai rangsang sebagai sesuatu yang sulit ataupun sesuatu yang bagus dan bermanfaat.

\section{Pemahaman Akuntansi}

Untuk mengetahui ada atau tidaknya pengaruh pemahaman akuntansi terhadap implementasi SAK EMKM, secara statistik akan diuji hipotesis sebagai berikut:

$\begin{aligned} \mathrm{H}_{\mathrm{o}}: \beta_{4}=0: & \text { Pemahaman Akuntansi tidak } \\ & \text { berpengaruh } \\ & \text { Implementasi SAK EMKM. } \\ \mathrm{H}_{\mathrm{a}}: \beta_{4} \neq 0 & \text { Pemahaman } \\ & \text { berpengaruh } \\ & \text { Implementasi SAK EMKM. }\end{aligned}$

Hasil pengujian parsial diperoleh nilai $t_{\text {hitung }}$ untuk pemahaman akuntansi sebesar 6,041, sedangkan nilai $t_{\text {tabel }}$ sebesar 1,986. Apabila $t_{\text {hitung }}$ dibandingkan dengan $t_{\text {tabel }}$ maka $t_{\text {hitung }}>t_{\text {tabel }}(6,041>1,986)$ dengan tingkat signifikan $0,000<0,05$. Hal ini berarti bahwa Ho ditolak dan Ha diterima. Kondisi ini 
bermakna bahwa sosialisasi SAK EMKM secara parsial berpengaruh positif terhadap implementasi SAK EMKM pada UMKM di Kota Bogor.

Pemahaman akuntansi yaitu mengerti dan memahami tentang pengetahuan akuntansi mengenai pembukuan dan penyusunan laporan keuangan dari usaha para UMKM. Orang yang mengerti dan pandai akan seluruh hal tentang akuntansi merupakan orang yang benar memiliki pemahaman akuntansi. Seseorang yang dikatakan paham dan pandai akuntansi adalah mengerti bagaimana proses itu dilaksanakan sampai menjadi suatu laporan keuangan dengan berdasar pada penyusunan laporan keuangan sesuai SAK. Pemahaman UMKM terhadap laporan keuangan sesuai standar akuntansi akan mendukung proses implementasi laporan keuangan berdasarkan SAK EMKM yang dapat membantu UMKM dalam mengembangkan usahanya. Peningkatan pemahaman baik untuk UMKM karena dengan membuat laporan keuangan sesuai SAK maka dapat memudahkan perusahaan, seperti mengetahui kinerja dan kekayaan perusahaan tersebut. Hasil penelitian ini mendukung penelitian Meidiyustiani (2016) dan teori Winkel (2004:274) yang menyatakan bahwa kemampuan dalam menangkap baik arti maupun makna dari mempelajari suatu bahan merupakan suatu pemahaman

Berikut hasil uji parsial untuk model regresi yang dijelaskan pada Tabel 15 :

\begin{tabular}{ccccc}
\multicolumn{5}{c}{ Tabel 15 : Rekapitulasi Uji t } \\
\hline No & Variabel & $\mathbf{t}_{\text {hitung }}$ & $\mathbf{t}_{\text {tabel }}$ & Ket \\
\hline 1 & Sosialisasi SAK EMKM & 2,784 & 1,986 & Berpengaruh \\
2 & Tingkat Pendidikan & 2,921 & 1,986 & Berpengaruh \\
3 & Pemilik & & & \\
4 & Persepsi Pelaku UMKM & 2,036 & 1,986 & Berpengaruh \\
& & 6,041 & 1,986 & Berpengaruh \\
\hline
\end{tabular}

Sumber: Data diolah, 2017

Berdasarkan Tabel 14 secara parsial sosialisasi SAK EMKM, tingkat pendidikan pemilik, persepsi pelaku UMKM dan pemahaman akuntansi mempunyai pengaruh terhadap implementasi SAK EMKM pada UMKM.

\section{Koefisien Determinasi}

Koefisien determinasi dilakukan untuk mengetahui besarnya kontribusi variabel sosialisasi SAK EMKM, tingkat pendidikan pemilik, persepsi pelaku UMKM dan pemahaman akuntansi terhadap implementasi SAK EMKM pada UMKM di Kota Bogor. Hasil analisis dapat dilihat pada Tabel 16 :

Tabel 16 : Koefisien Determinasi Model Summary ${ }^{b}$

\begin{tabular}{lrrrr}
\hline Model & $\mathrm{R}$ & $\begin{array}{c}\mathrm{R} \\
\text { Square }\end{array}$ & $\begin{array}{r}\text { Adjusted } \\
\text { R Square }\end{array}$ & $\begin{array}{c}\text { Std. Error } \\
\text { of the } \\
\text { Estimate }\end{array}$ \\
\hline 1 &, $759^{\mathrm{a}}$ &, 575 &, 557 & 1,178 \\
\hline
\end{tabular}

a. Predictors: (Constant), Pemahaman Akuntansi, Sosialisasi SAK EMKM, Tingkat Pendidikan Pemilik, Persepsi Pelaku UMKM

b. Dependent Variable: Implementasi SAK EMKM

Sumber: Output pengolahan data dengan SPSS 22, 2017

Berdasarkan Tabel 14 diperoleh angka $\mathrm{R}^{2}$ ( $\mathrm{R}$ square) sebesar 0,575 atau $57,5 \%$. Hal ini menunjukan bahwa kontribusi sosialisasi SAK EMKM, tingkat pendidikan pemilik, persepsi pelaku UMKM dan pemahaman akuntansi terhadap implementasi SAK EMKM sebesar 57,5\% sedangkan sisanya $42,5 \%$ dijelaskan oleh variabel yang tidak dimasukan dalam model penelitian ini seperti pengetahuan akuntansi, motivasi pemilik dan latar belakang pendidikan.

\section{SIMPULAN}

1. Sosialisasi SAK EMKM, tingkat pendidikan pemilik, persepsi pelaku UMKM dan pemahaman akuntansi secara simultan berpengaruh positif terhadap implementasi SAK EMKM pada UMKM di Kota Bogor.

2. Sosialisasi SAK EMKM, tingkat pendidikan pemilik, persepsi pelaku UMKM dan pemahaman akuntansi secara parsial berpengaruh positif terhadap implementasi SAK EMKM pada UMKM di Kota Bogor.

3. Berdasarkan hasil pengujian koefisien regresi dapat diketahui bahwa faktor yang paling dominan pada implementasi SAK 
EMKM pada UMKM di Kota Bogor adalah pemahaman akuntansi.

\section{DAFTAR PUSTAKA}

Dewi, Yuniarta dan Wahyuni, 2017, Pengaruh Sosialisasi SAK ETAP, Tingkat Pendidikan Pemilik dan Persepsi Pelaku UKM terhadap Penggunaan SAK ETAP pada UKM di Kecamatan Buleleng, Jurnal Akuntansi Volume 7 No.1 Tahun 2017, Universitas Pendidikan Ganesha.

Hariandja, Marihot T.E, 2002, Manajemen Sumber Daya Manusia, Jakarta: Grasindo.

Meidiyustiani, Rinny, 2016, Pengaruh Pendidikan Pemilik, Pemahaman Akuntansi dan Motivasi Pemilik terhadap Penerapan Standar Akuntansi Keuangan untuk Entitas Tanpa Akuntabilitas Publik, Jurnal Akuntansi Vol.1 No.01 hal 13-27, Universitas Budi Luhur.

Mukmin, Mas Nur dan Siti Maemunah, 2018, Analisis Pengelolaan Dana Pemerintah Desa Pada Kecamatan Babakan Madang, Sukaraja Dan Ciawi, Jurnal Akunida Vol. 4 No. 2 hal 73-85, Universitas Djuanda.

Murniati, 2002, Investigasi Faktor-Faktor Yang Mempengaruhi Penyiapan dan Penggunaan Informasi Akuntansi Perusahaan Kecil dan Menengah, Semarang: SNA 5.

Neag, Romana, 2011, Differential Financial Reporting for Micro Entities: Advantages and Limits, Universitatea Petru Maior, Romania, 2(14), 181187.

Nugroho, Yohanes Anton, 2011, It's Easy Olah Data dengan SPSS, Skripta Media Creative, Yogyakarta.

Priyatno, Duwi, 2013, Analisis Korelasi, Regresi dan Multivariate dengan SPSS, Yogyakarta : Gava Media.

Riduwan dan Sunarto, 2007, Metode dan Teknik Menyusun Tesis, Cetakan Ketiga, Alfabeta, Bandung.

Robbins, Stephen P, 2003, Organizational Behaviour, Tenth Edition (Perilaku
Organisasi Edisi ke Sepuluh), Jilid 2, Alih Bahasa Drs. Benyamin Molan. Jakarta : PT. Macanan Jaya Cemerlang.

Simamora, Bilson, 2002, Panduan Riset Perilaku Konsumen, Surabaya: Pustaka Utama.

Sugiyono, 2007, Statistika Untuk Penelitian, Penerbit Alfabeta, Bandung. 2012, Metode Penelitian Kuantitatif, Kualitatif dan $R \& D$, Alfabeta, Bandung.

2013, Metode Penelitian

Kombinasi, Alfabeta, Bandung. 2014, Cara Mudah Menyusun:

Skripsi, Tesis, dan Disertasi, Alfabeta, Bandung.

Supardi, 2005, Metodologi Penelitian Ekonomi dan Bisnis, Yogyakarta : UII Press.

Undang-Undang Republik Indonesia, Nomor 20 Tahun 2008 tentang Usaha Mikro Kecil Menengah.

Usman, Nurdin, 2002, Konteks Implementasi Berbaisis Kurikulum, Yogyakarta: Bintang Pustaka.

Winkel, 2004, Psikologi Belajar, Jakarta : PT. Gramedia Pustaka Utama. 